\title{
Short-Term Change Detection and Markov Chain Prediction of Greenhouse Areas in Alanya, Turkey Using Sentinel-2 Imageries
}

\author{
Melis Inalpulat ${ }^{1 *}$, Levent Genc ${ }^{2}$

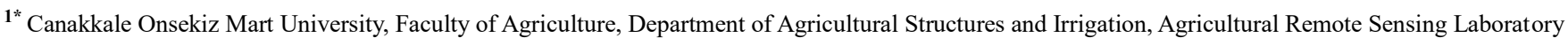 \\ (AGRESEL), Computer-Agriculture-Planning (ComAgPlan) Study Group, Canakkale, Turkey, (ORCID: 0000-0001-7418-1666), melisinalpulat@gmail.com \\ ${ }^{2}$ Canakkale Onsekiz Mart University, Faculty of Architecture and Design, Department of Urban and Regional Planning, Land Use and Climate Change Laboratory \\ (LUCC-Lab.), Computer-Agriculture-Planning (ComAgPlan) Study Group, Canakkale, Turkey, (ORCID: 0000-0002-0074-0987), leventgc@gmail.com
}

(First received 4 November 2021 and in final form 26 December 2021)

(DOI: 10.31590/ejosat.1019033)

ATIF/REFERENCE: Inalpulat, M. \& Genc, L. (2021). Short-Term Change Detection and Markov Chain Prediction of Greenhouse Areas in Alanya, Turkey Using Sentinel-2 Imageries. European Journal of Science and Technology, (31), 776-782.

\begin{abstract}
Greenhouses provide controlled growth conditions and possibility off-season production for various agricultural products while there are some reported adverse effects on the environment due to particularly increased plastic waste, changed soil properties, and ecosystem degradation in their extensive use. Monitoring recent status and forecasting future probabilities of greenhouse coverage (ha, \%) comprise influential tool for researchers and planners to reach more sustainable and environmental-friendly situations. Present paper deals with detection of short-term changes in greenhouse areas using high resolution Sentinel-2 imageries, and prediction of probable future status via markov chain model within Alanya, Turkey. The changes in greenhouse coverages were evaluated considering initial acquisition year of imageries, and change analyses were conducted between 2015 and 2021 years. Use of a Landsat-derived plastic greenhouse index to discriminate between greenhouse and other surrounding land cover land use (LCLU) types was tested for Sentinel-2. The LCLU 2015 and LCLU 2021 maps were consisted of five main classes including natural vegetation, open agricultural field, water surface, concrete structure, and greenhouse. Classification accuracies were assessed by checking the actual statuses of 200 equalized random control points using Google Earth application. The changes in LCLU within the major greenhouse located zone were evaluated through post-classification comparison technique. Future greenhouse areas, as well as other LCLU types, were predicted through markov chains for 2027 year by considering the same time interval. Findings have revealed that greenhouse areas have remarkably increased in the last years, and have great potential to continue expanding in the near future. Utilization of the index imageries to increase the classification accuracy of greenhouses is recommended.
\end{abstract}

Keywords: Alanya, Change detection, Greenhouse, Markov chain prediction, Sentinel-2.

\section{Sentinel-2 Görüntüleri Kullanılarak Alanya, Türkiye’ deki Örtüaltı Alanlarının Kısa Dönem Değişiminin Belirlenmesi ve Markov Zinciri Tahminlemesi}

Öz

Örtüaltı yetiştiriciliği birçok tarımsal ürün için kontrollü büyüme şartları ve mevsimden bağımsız üretim olanağı sağlarken, yoğun kullanılmaları durumunda artan plastik atıklar, değişen toprak özellikleri ve çevresel bozunumdan dolayı rapor edilmiş bazı olumsuz etkileri de bulunmaktadır. Daha sürdürülebilir ve çevre dostu koşullara ulaşmak için örtüaltı yetiştiriciliği alanlarının (ha, \%) hâlihazırdaki durumunun izlenmesi ve gelecekteki olası alanların tahminlenmesi, araştırmacılar ve planlayıcılar için etkili araçlardır. $\mathrm{Bu}$ çalışma Alanya' da yer alan örtüaltı yetiştiriciliği yapılan alanlarda kısa dönemde meydana gelen değişimlerin yüksek çözünürlüklü Sentinel-2 görüntüleri kullanılarak belirlenmesi ve gelecekteki olası durumun markov zinciri modeli aracılığı ile tahminlenmesine odaklanmıştır. Örtüaltı alanlarındaki değişimler, görüntülerin ilk alındığı tarih gözetilerek değerlendirilmiş ve değişim analizleri 2015 ile 2021 yılları arasında yürütülmüştür. Landsattan türetilmiş bir plastik örtüaltı indeksinin, örtüaltı alanları ve etrafındaki diğer arazi örtüsü ve arazi kullanımı (AÖAK) tiplerinin birbirinden ayrılabilmesinde kullanımı Sentinel-2 için test edilmiştir. $\mathrm{AÖAK}_{2015}$ ve $\mathrm{AÖAK}_{2021}$ haritaları doğal vejetasyon, açık tarım alanı, su yüzeyi, betonarme yapılar ve örtüaltı sınıfları olmak üzere beş ana sınıftan oluşmuştur. Sınıflama doğrulukları, sınıflardan rastgele ve eşit miktarda atanan 200 kontrol noktasının doğruluğu Google Earth uygulaması ile kontrol edilerek değerlendirilmiştir. Örtüaltı alanlarının bulunduğu ana zonda meydana gelen AÖAK değişimleri sınıflama sonrası karşılaştırma tekniği ile değerlendirilmiştir. Gelecekteki örtüaltı alanları, diğer AÖAK sınıflarında olduğu üzere, markov zinciri modeli ile ayrı yıl aralığı göz önünde bulundurularak 2027 yılı için tahminlenmiştir.

*Corresponding Author: melisinalpulat@gmail.com 
Bulgular, geçtiğimiz yıllarda sera alanlarının fark edilebilir biçimde arttığını ve yakın gelecekte de gelecekte de bu alanların büyük bir genişleme potansiyelinin bulunduğunu göstermiştir. Örtüaltı alanların sınıflama doğruluğunun artırılması için indeks görüntülerinin kullanımı önerilmiştir.

Anahtar Kelimeler: Alanya, Değişim belirlenmesi, Markov zincir tahminlemesi, Örtüaltı, Sentinel-2.

\section{Introduction}

Greenhouse systems are reported to be convertion of traditional agriculture into more controlled conditions using industrial and technological approaches, which was mainly prompted by conditioning urban features to rural, in terms of using covering materials for agricultural production purposes (Levin et al., 2007). These systems provide continuous production independent from seasons due to controlled growth conditions by protecting the plants not only from inappropriate weather conditions but also from insects or diseases, and provides optimization of water use, and thus, widely used in various regions of the world since the late 40s (Gernaud, 2000; Jiang and Yu, 2008; Jimenez-Lao et al., 2020). This type of production systems are also reported to be significant for economic and employment situations, as well as food security (Sonmez and Sari, 2006). Therefore, the coverage of greenhouse areas is progressively increasing. In fact, the extent of greenhouse coverages has reported to reach approximately 3020 million hectares, whereas the majority of the greenhouses are located in China, Mediterranean countries, North Africa and Middle East (Wu et al., 2016).

Besides the advantages of protected production in greenhouse conditions, there are some adverse impacts on the environment. Researchers emphasized that increment in especially plastic coverage may lead to decreased plant biodiversity, degradation of soil properties, increased level of residues, increased level of contamined and eutrophicated water resources, and fragmentation sourced from LCLU changes ( $\mathrm{Lu}$ et al., 2014; Parra et al., 2008; Thompson et al., 2020). In both positive and perspectives of greenhouse production, determination of the changes in a specified area presents an important step for assessing the recent status and forecasting future conditions. At this juncture, remote sensing (RS) data for investigation of such changes in different spectral, spatial and temporal resolutions have long been used for pixel- and objectbased determination of greenhouse areas with different aspects. For instance, Ma et al. (2021) highlighted the significance of high resolution RS imageries in estimation of vegetable yields in greenhouses, while Li et al. (2020) mentioned the necessity of greenhouse film monitoring as an environmental issue, by considering medium and high resolution satellite imageries. However, there are some limitations for greenhouse mapping and monitoring due to the fact that differentiation in coverage materials variates the spectral signatures of these greenhouses (Tarantino and Figorito, 2012). Different indices related to greenhouse determination were proposed by researchers including different band ratios of electromagnetic spectrum, for instance, Lu et al. (2014), Sun et al. (2021), and Themistocleous (2020).

In present study, it was aimed to determine the short-term changes in greenhouse areas between 2015 and 2021 years in Alanya city using Sentinel-2 imageries, and to predict the coverage of greenhouses in 2027 year depending on the past statuses through markov chain model. In addition to the oriinal imageries, performance of a Landsat-based plastic greenhouse index for discrimination of greenhouses in selected area of interest was evaluated through $\mathrm{LCLU}_{2015}$ and $\mathrm{LCLU}_{2021}$ maps to achieve the aims.

\section{Material and Method}

\subsection{Study area}

Study is conducted in Alanya city of Antalya province, Turkey (Figure 1a). Alanya city presents typical Mediterranean climate and vegetation characteristics. Agriculture is one of the two essential economic sources in the area. Growth of diverse agricultural products is possible due to suitable soil and climatic conditions whereas many tropical fruits are specifically grown in the area, and transport to different regions. Greenhouse production has a key role in the continuous productvity of various agricultural plants in the study area, as well as in whole Mediterranean region. Eventhough, classification and accuracy assessment procedures were conducted in whole city, results were interpreted within $10 \mathrm{~km}$ buffer zone from coastal line, where the greenhouses are intensively located (Figure 1b).

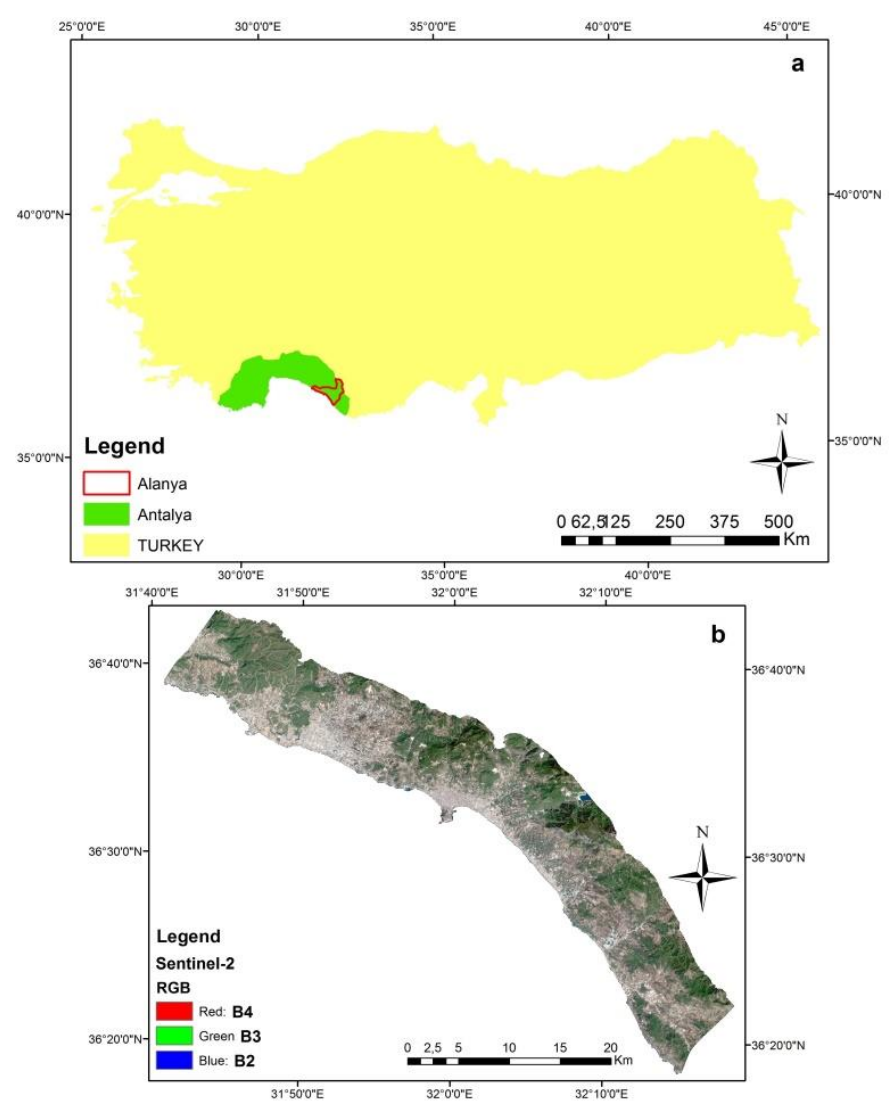

Figure 1 a) Location of Alanya in Antalya Province and Turkey, b) Study area

Şekil 1 a) Alanya' nın Antalya İli ve Türkiye' deki konumu, b) Çalış̧ma alanı

\subsection{Sentinel-2 imageries}

Available cloudless imageries of Sentinel-2 imageries, which are provided by European Space Agency (ESA), were 
freely downloaded from United States Geological Survey (USGS) Earth Explorer web portal (https://earthexplorer.usgs.gov). The study area is covered by two pairs of Sentinel-2 imageries with tiles of T36SUF and T36SVF, which were mosaicked in image pre-processing step for each date. The imageries of were seleced from the same month of each year to eliminate probable differencies in illimunation conditions and production paterns, and the acqusition dates of imageries are 26 August, 2015 and 24 August, 2021. Sentinel-2 imageries have thirteen bands covering different parts of electromagnetic spectrum with various spatial resolutions with 10, 20 and $60 \mathrm{~m}$. The central wavelenght $(\mathrm{nm})$, band width (nm), and spatial resolution (m) properties of bands are given in Table 1 (https://sentinels.copernicus.eu).

Table 1 Properties of Sentinel-2 bands

Tablo 1 Sentinel-2 bantlarının özellikleri

\begin{tabular}{cccc}
\hline Band & $\begin{array}{c}\text { Central } \\
\text { Wavelenght }(\mathrm{nm})\end{array}$ & $\begin{array}{c}\text { Band Width } \\
(\mathrm{nm})\end{array}$ & $\begin{array}{c}\text { Spatial } \\
\text { Resolution }(\mathrm{m})\end{array}$ \\
\hline 1 & 443 & 21 & 60 \\
2 & 492 & 66 & 10 \\
3 & 560 & 36 & 10 \\
4 & 665 & 31 & 10 \\
5 & 704 & 15 & 20 \\
6 & 740 & 15 & 20 \\
7 & 783 & 20 & 20 \\
8 & 833 & 106 & 10 \\
$8 \mathrm{a}$ & 865 & 21 & 20 \\
9 & 945 & 20 & 60 \\
10 & 1374 & 31 & 60 \\
11 & 1614 & 91 & 20 \\
12 & 2202 & 175 & 20 \\
\hline
\end{tabular}

\subsection{Image Pre-Processing, Classification and Accuracy Assessment Procedures}

Prior to the image classification step, the $20 \mathrm{~m}$ bands of each date and tile were resampled to $10 \mathrm{~m}$. Subsequently, the resampled bands were stacked, and multispectral images of two tiles were mosaicked for each date to obtain full coverage of Alanya city subset. Moreover, a retroregressive plastic greenhouse index (RPGI) which was offered for Landsat ETM+ imageries by Yang et al. (2017) were calculated (1) to determine whether it presents higher classification accuracy for greenhouse areas than the original imageries in the specified area.

$$
R P G I=\frac{R_{\text {Blue }}}{1-\text { mean }\left(R_{\text {Blue }}+R_{\text {Green }}+R_{\text {NIR }}\right)}
$$

The original multispectral images and RPGI images were classified to generate $\mathrm{LCLU}_{2015}$ and $\mathrm{LCLU}_{2021}$ using one of the most widely used classification algorithym of maximum likelyhood. The training samples were randomly collected from five main classes namely natural vegetation $(\mathrm{N})$, open agricultural field (A), water surface (W), concrete structure (C), and greenhouse $(\mathrm{G})$.

The reliabilities of classifications were evaluated though accuracy assessment procedures and the accuracy of 200 control points that were randomly and equally distributed for each class were assessed via high resolution Google Earth images of 2015 and 2021 years according to Congalton and Green (2009). Overall accuracy (OA) and overall kappa statsitics were considered for whole classification whereas producer's accuracies and user's accuracies and class kappas (CA) were utilized to determine the reliabilities at class-level depending on equations from 2 to 8 , respectively.

$$
\begin{aligned}
& O A=\frac{\text { Total Correctly Classified }}{\text { Total Classified }} \times 100(2) \\
& \mathrm{PA}=\frac{\text { Correctly Classified Points }}{\text { Class Reference Points }} \times 100(3)
\end{aligned}
$$

$$
\begin{aligned}
& U A=\frac{\text { Correctly Classified Points }}{\text { Total Classified Points for Class }} \times 100 \text { (4) } \\
& K=\frac{P_{o}-P_{c}}{1-P_{c}}=\frac{N \sum_{i=1}^{r} x_{i i}-\sum_{i=1}^{r} x_{i+*} x_{+i}}{N^{2}-\sum_{i=1}^{r} x_{i+*} x_{+i}}=\frac{\left(\sum P_{i i}\right)-\left(\sum P_{i}+P+j\right)}{1-\left(\sum P_{i}+P+j\right)}(5) \\
& P_{o}=\sum P_{i i}=\frac{\text { Total CoRrectly Classified Points }}{\text { Total Points }} \text { (6) } \\
& P_{c}=\sum P_{i}+P+j(7) \\
& P_{c}=\frac{\left(\frac{(\text { lass1 Row total } . \text { S } 1 \text { Column total }}{\text { Total Points }}\right)+\cdots+\left(\frac{\text { Class } 5 \text { Row Total } \times \text { Sj Column Total }}{\text { Total Points }}\right)}{\text { Total Points }}(8)
\end{aligned}
$$

\subsection{Future Prediction}

Furthermore, depending on the past LCLU statuses, future greenhouse areas were predicted using markov chain model for 2027 year together with other LCLU types, by considering the same time interval. The model was initially used by Burnham (1973), with the aim of future LCLU modelling by considering the changes between two dates occurred in a certain area (Sang, 2011; Hamad, 2018) $(9,10$, and 11).

$$
\begin{gathered}
S(t, t+1)=P_{i j} \times S(t)(9) \\
P_{i j}=\left[\begin{array}{cccc}
P_{11} & P_{12} & \ldots & P_{1 n} \\
P_{21} & P_{22} & \ldots & P_{2 n} \\
\ldots & \ldots & \ldots & \ldots \\
P_{n 1} & P_{n 2} & \ldots & P_{n n}
\end{array}\right](10) \\
0 \leq P_{i j} \leq 1(11)
\end{gathered}
$$

where $S(t)$ and $S(t+1)$ are the statuses of time , andt time $_{2}$, respectively, $P i j$ is transition probability matrix, $P$ is transition probability. $P i j$ represents probability for transition of state $i$ to $j$ in time 2 , ranging from 0 to $1 ; P n$ is the state probability of a certain time.

Prediction module of the publicly available future land use simulation model was used to obtain number of pixels for each class of 2027, which were later converted to survey area coverage (https://www.geosimulation.cn/FLUS.html). The LCLU maps with more accurate greenhouse classifications were decided to be used used in the prediction process. 


\section{Results and Discussion}

\subsection{Classification Accuracy and LCLU maps}

The results of accuracy assessments have revealed that, 2015 images seemed more accurately classified than 2021. This situation mainly sourced from the complexity of LCLU pattern presenting mixed spectral characteritics particularly where the construction processes are still ongoing. Furthermore, OA and OK of LCLU maps obtained from original band imageries of both years were quite higher than RPGI index-derived LCLU maps (Table 2 and Table 3). The OA of 2015 from original and index imageries were $86 \%$ and $84 \%$ with $\mathrm{OK}$ values of 0.8250 and 0.8000 , respectively. The PA of original imagery based LCLU maps were ranged between $80 \%$ and $100 \%$ for 2015 , as well as UAs. The PA values of LCLU maps derived from original bands were varied from $70 \%$ to $100 \%$ whereas UAs were ranged between $80 \%$ and $100 \%$ for 2021 . Accordingly, investigation $\mathrm{PA}, \mathrm{UA}$, and $\mathrm{CA}$ for individual classes demonstrated that eventhough $\mathrm{OA}$ and $\mathrm{OK}$ were higher for LCLU maps obtained from original imageries, $\mathrm{G}$ areas could be classified more accurately in index-derived LCLU maps (Table $2-4)$. The $C A$ values for $G$ class were increased from 0.7500 to 0.8624 in 2015 and from 0.7154 to 0.7962 in 2021 by using RPGI index-derived LCLU maps.

Table 2 Overall accuracies and class accuracies of 2015 year

Tablo 22015 yılı toplam doğruluklar ve sinıf doğrulukları

2015

\begin{tabular}{lllll} 
Classes & \multicolumn{2}{c}{ Original LCLU } & \multicolumn{2}{c}{ Index LCLU } \\
& OA $86.00 \%$ OK 0.8250 & OA $84.00 \%$ OK 0.8000 \\
& PA (\%) & UA (\%) & PA (\%) & UA (\%) \\
\hline N & 81.82 & 90.00 & 72.73 & 80.00 \\
C & 80.00 & 80.00 & 77.78 & 70.00 \\
A & 88.89 & 80.00 & 88.89 & 80.00 \\
W & 100.00 & 100.00 & 100.00 & 100.00 \\
G & 80.00 & 80.00 & 81.82 & 90.00 \\
\hline
\end{tabular}

Table 3 Overall accuracies and class accuracies of 2021 year

Tablo 32021 yılı toplam doğruluklar ve sınıf doğrulukları

$$
2021
$$

Classes Original LCLU Index LCLU

$$
\text { OA } 82.00 \% \text { OK } 0.7750 \quad \text { OA } 80.00 \text { OK } 0.7500
$$

\begin{tabular}{lllll} 
& PA $(\%)$ & UA $(\%)$ & PA $(\%)$ & UA $(\%)$ \\
\hline N & 88.89 & 80.00 & 70.00 & 70.00 \\
C & 81.82 & 90.00 & 80.00 & 80.00 \\
A & 77.78 & 70.00 & 63.64 & 70.00 \\
W & 100.00 & 100.00 & 100.00 & 100.00 \\
G & 63.64 & 70.00 & 88.89 & 80.00 \\
\hline
\end{tabular}

Table 4 Class kappa values of 2021 year

Tablo 42021 yılına ait sınıf kappa değerleri

\begin{tabular}{lcccc}
\hline Years & \multicolumn{2}{c}{2015} & \multicolumn{2}{c}{2021} \\
\hline Classes & $\begin{array}{c}\text { Original } \\
\text { LCLU }\end{array}$ & $\begin{array}{c}\text { Index } \\
\text { LCLU }\end{array}$ & $\begin{array}{c}\text { Original } \\
\text { LCLU }\end{array}$ & $\begin{array}{c}\text { Index } \\
\text { LCLU }\end{array}$ \\
& $\mathrm{CA}$ & $\mathrm{CA}$ & $\mathrm{CA}$ & $\mathrm{CA}$ \\
\hline $\mathrm{N}$ & 0.8718 & 0.7436 & 0.7664 & 0.7250 \\
$\mathrm{C}$ & 0.7500 & 0.6341 & 0.8812 & 0.7500 \\
$\mathrm{~A}$ & 0.7872 & 0.7561 & 0.7348 & 0.6564 \\
$\mathrm{~W}$ & 1.0000 & 1.0000 & 1.0000 & 1.0000 \\
$\mathrm{G}$ & 0.7500 & 0.8624 & 0.7154 & 0.7962 \\
\hline
\end{tabular}

Depending on the accuracy-related findings, the overall classifications were higher for original band based LCLU maps whereas index-derived LCLU maps gave better classification accuracy for $\mathrm{G}$ class, but weak overall classification. Therefore, LCLU $_{2015}$ and LCLU 2021 obtained from original bands were represented to designate LCLU status of study area (Figure 2a, b). Furthermore, the more accurate $G$ areas from index-derived LCLU was represented on Sentinel-2 imageries in Figure $3 a, b$.

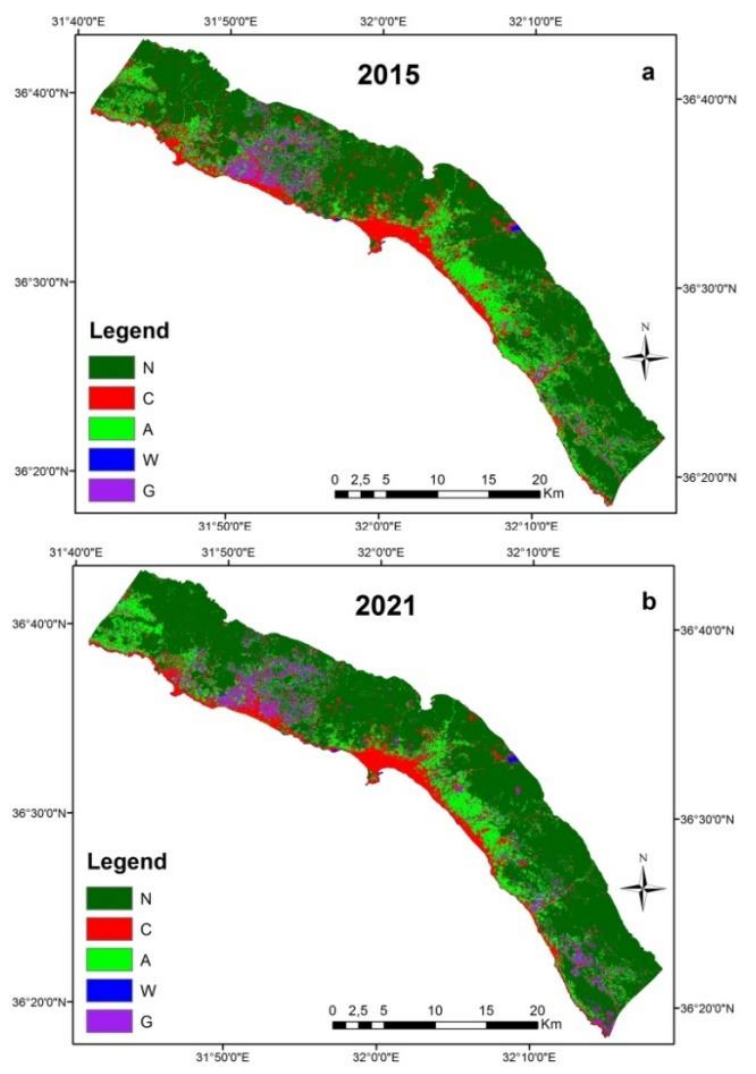

Figure 2 LCLU maps obtained from original band imageries a) $L C L U_{2015}$, and b) $L C L U_{2021}$ 
Şekil 2 orijinal bant görüntülerden elde edilen a) $A O A K_{2015}$ ve b) $A O A K_{2021}$

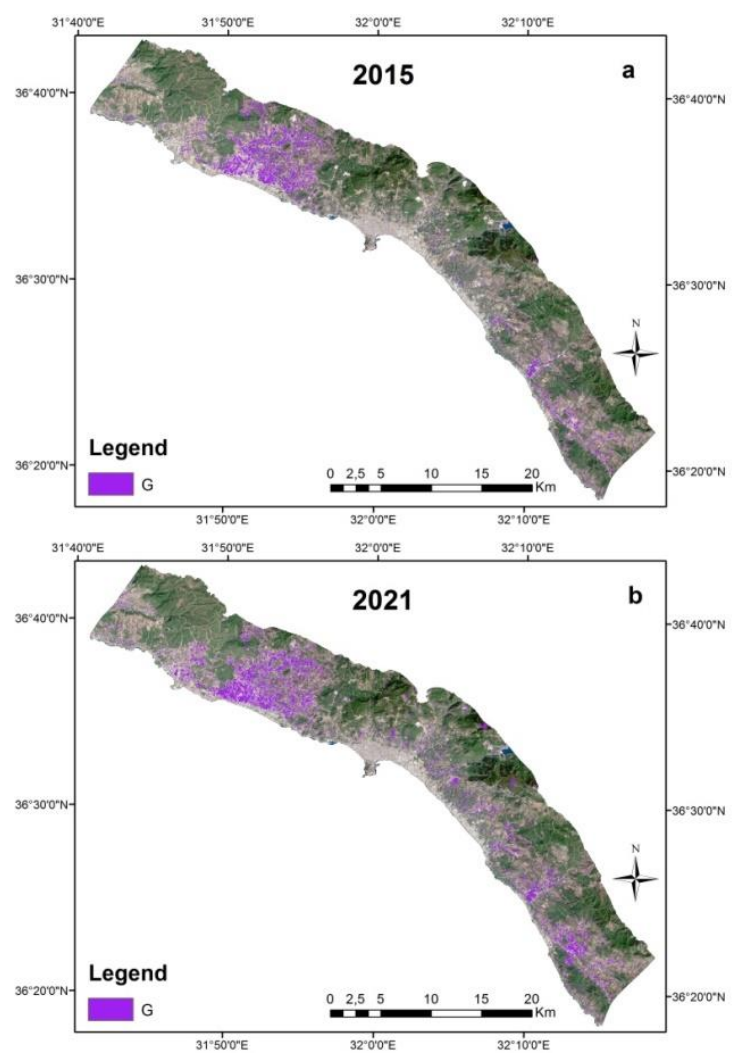

Figure 3 Greenhouse areas obtained from RPGI LCLU maps a) 2015, and b) 2021

Sekil 3 RPGI AOAK haritalarından elde edilen örtüaltı alanları a) 2015 ve b) 2021

\subsection{LCLU Changes}

As it is mentioned before, although the $\mathrm{OA}$ and $\mathrm{OK}$ of LCLU maps obtained from original band imageries were quite higher, the index-derived maps with more accurate $G$ classification were used in the further steps in respect to concepts of the study. Accordingly, the coverage of $\mathrm{G}$ areas was increased from $5.2 \%$ to $7.5 \%$ with an increment of $2.3 \%$ (Figure 4). The $\mathrm{C}$ class areas showed an increment tendency, as well as $\mathrm{G}$ areas. The increase in $\mathrm{C}$ areas is probable to be eventuated against the needs and preferences of growing population in the area. There was a slight decrease from $62.4 \%$ to $62.1 \%$.in $\mathrm{N}$ areas, which was mainly sourced from misclassifications. The decrease occurred in A class areas (2.7\%) against the increments of $\mathrm{G}$ and $\mathrm{C}$ areas together.

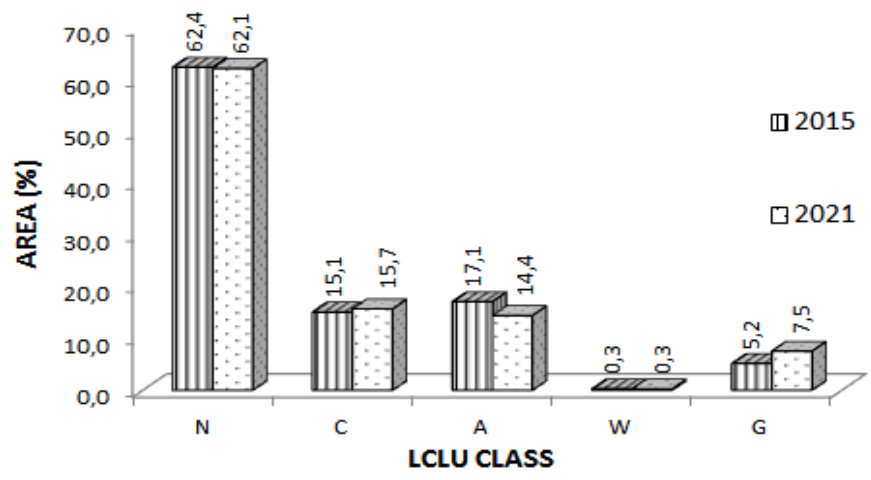

Figure 4 Temporal changes in LCLU class areas (\%)

Şekil 4 AOAK sınıf alanlarındaki zamansal değişimler (\%)

\subsection{Future Status of Greenhouse Areas}

The future areas for LCLU classes were predicted depending on the transition probabilities ranging between 0 and 1 , whereby higher values represents higher probability of occurance. The transition probability of A class to $G$ seemed comparatively higher than the other class-to-class transitions (Table 5). It was followed by the probability of $\mathrm{C}$ to $\mathrm{G}$ transition, which was occurred due to spectral similarity of bare soils especially located around the recently constructed $\mathrm{G}$ areas. Furthermore, predicted percentage areas (\%) of each LCLU class are given in Figure 5. The most observable change is predicted to occur in A class with a decrease of 3.5\%. Main reason of this reduction seemed strongly related to high transition probability to $\mathrm{G}$ areas, which was followed by transition probability to $\mathrm{C}$ class. On the contrary, the $\mathrm{G}$ class coverage is expected to increase by $2.8 \%$ and reach to $10.3 \%$ in the middle of 2027 . In addition, almost $1 \%$ increase was predicted for $\mathrm{C}$ class coverage. Finding designated that the urban expansion rate was smaller than $G$ class expansion in the area for the investigated time interval. On the other hand, the predicted decrease in $\mathrm{N}$ areas was only $0.1 \%$. Finally, there is negligible change in $\mathrm{W}$ class according to predicted values, which was not observable in percent area level (\%).

Table 5 Transition probabilities of LCLU classes

Tablo 5 AOAK sınıflarının dönüşüm olasılıkları

\begin{tabular}{llllll}
\hline Class & $\mathrm{N}$ & $\mathrm{C}$ & $\mathrm{A}$ & $\mathrm{W}$ & $\mathrm{G}$ \\
\hline $\mathrm{N}$ & 0.904784 & 0.019841 & 0.052081 & 0.000001 & 0.023293 \\
$\mathrm{C}$ & 0.085873 & 0.562849 & 0.077774 & 0.001174 & 0.272330 \\
$\mathrm{~A}$ & 0.070712 & 0.090480 & 0.492353 & 0.000001 & 0.346454 \\
$\mathrm{~W}$ & 0.000590 & 0.003071 & 0.004816 & 0.984816 & 0.006707 \\
$\mathrm{G}$ & 0.022160 & 0.103910 & 0.010058 & 0.000691 & 0.863181 \\
\hline
\end{tabular}

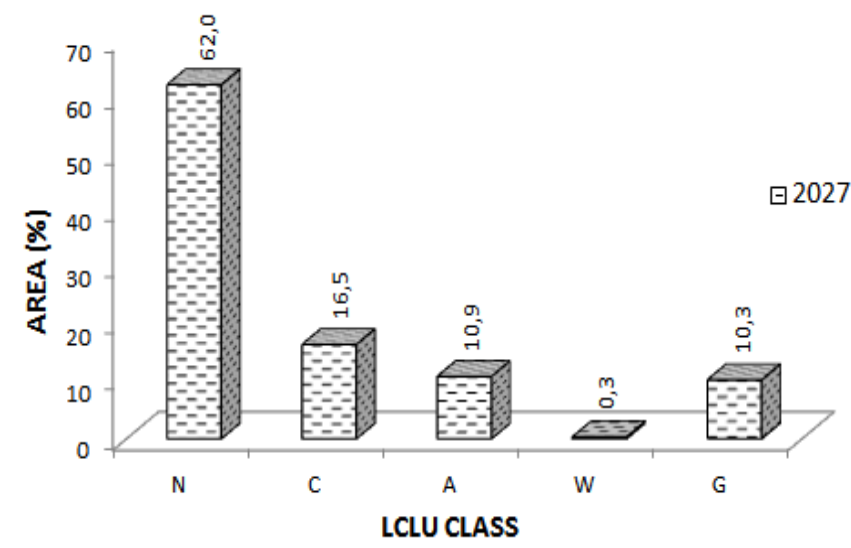

Figure 5 Predicted LCLU class areas (\%) for 2027

Şekil 52027 yıl için tahminlenen AOAK sınıf alanların (\%) 


\subsection{Discussion}

Greenhouse production is known to compose the major part of conversion process from extensive to intensive farming which brings various benefits on production, as well as some negative impacts on the environment (Yang et al., 2017). Therefore, mapping and temporaly monitoring of greenhouse areas have become a significant area of interest among researchers from different disciplines such as; agriculture, environment, and rural planning. In this context, remote sensing imageries are presenting valuable datasets for this purpose, and provide rapid, reliable and relatively economic results at different scales. Particularly, increase of publicly available satellite imageries that acquired from different sensors with various resolutions has accelerated the number of studies conducted in related research area. Object- and pixel-based approaches have long been applied to satellite imageries with different spatial, spectral and temporal resolutions for discrimination of greenhouses by different researchers (Aguilar et al., 2015; Koc-San, 2013; Novelli et al., 2016). In addition to investigation of past and present status of greenhouse areas, determination of potentially suitable areas for new greenhouses presents a contemporary topic in last few years (Cemek et al., 2017; Rezaeiniya et al, 2014; Saltuk, 2019).

In present study, short-term changes were investigated through historic LCLU maps and future condition was predicted depending on the past statuses. In addition to original imageres, RPGI index was composed to be used in classification process. All generated LCLU maps designated that great majority of $\mathrm{G}$ class areas are located within a $10 \mathrm{~km}$ zone from the coastal line of Alanya. Thence, a buffer zone was composed to extract this part from whole city coverage, and results were interpreted for this specific area of interest. The results of accuracy assessments have uncovered that $\mathrm{G}$ areas could be classified more accurately using RPGI index, whereby the classified $G$ areas were also coherent with Turkish Statistical Institute (TUIK) database of greenhouse area for both years (https://biruni.tuik.gov.tr). Findings also revealed that there was considerable change in $G$ class coverage within the studied time period, and the trend is foreseened to continue in the next few years. The predicted increase of $\mathrm{G}$ coverage within study area is approximately $3 \%$, and this corresponds to $36.73 \%$ expansion rate for $G$ class between 2021 and 2027, which seemed quite fast for a 7-year period. Therefore, more controlled and environmental-friendly approaches should be considered in the area to avoid undesired effects of rapid changes in the study area.

\section{Conclusions and Recommendations}

Present study focused on the determination and prediction of short-term changes around main greenhouse locations of Alanya, Turkey, whereas the initial study year was selected in respect to availability of Sentinel-2 imageries. Use of RPGI index, which was offered for Landsat ETM+, was investigated for specified study area, and gave satisfactory results in terms of higher accuracy for $\mathrm{G}$ area classificationIn brief, study may provide a better undertanding of both LCLU and greenhouse area changes in the considered time period within the specified area. It presents the first greenhouse prediction study in the selected area of interest, and believed to have potential to assist the planning approaches for planners and decision makers in the local authorities. A study is planned for simulation of future greenhouse areas in a sustainable way in Antalya Province, Turkey, using Sentinel-2, together with soil, climate, and terrain properties, and other ancillary data.

\section{Acknowledge}

The satellite data have obtained from United States Geological Survey (USGS). The Future Land Use Simulation (FLUS) model was downloaded from Geographical Simulation and Optimization Systems (GeoSOS) website.

\section{References}

Aguilar, M.A., Vallario, A., Aguilar, F.J., Lorca, A.G., Parente, C. (2015). Object-based greenhouse horticultural crop identification from multi-temporal satellite imagery: A case study in Almeria, Spain. Remote Sening, 7, 7378-7401.

Burnham, B.O. (1973). Markov intertemporal land use simulation model. Southern Journal of Agricultural Economics., 5, 253-258.

Cemek, B., Guler, M., Arslan, H. (2017). Spatial analysis of climate factors used to determine suitability of greenhouse production in Turkey. Theorotical and Applied Climatology, $128,1-11$.

Congalton, RG., Green, K. (2009). Assessing the Accuracy of Remotely Sensed Data: Principles and Practices. $2^{\text {nd }}$ Ed. Lewis Publishers, Boca Raton.

Garnaud, J.C. (2000). Plasticulture: Bulletin du comité international des plastiques en agriculture. Plasticulture, 119, 30-43.

Hamad, R., Balzter, H., Kolo, K. (2018). Predicting land use/land cover changes using a CA-Markov model under two different scenarios. Sustainability, 10, 3421. https://doi:10.3390/su10103421

Jiang, W.J., Yu, H.J. (2008). Present situation and future development for protected horticulture in mainland China. In Proceedings of the Acta Horticulturae; International Society for Horticultural Science, 770, 29-35.

Jimenez-Lao, R., Aguilar F.J., Nammaoui, A., Aguilar, M.A. (2020). Remote sensing of agricultural greenhouses and plastic-mulched farmland: An Analysis of Worldwide Research. Remote Sensing, 12, 2649. https://doi:10.3390/rs12162649

Koc-San, D. (2013). Evaluation of different classification techniques for the detection of glass and plastic greenhouses from WorldView-2 satellite imagery. Journal of Applied Remote Sensing, 7(1), 073553. https://doi.org/10.1117/1.JRS.7.073553

Levin, N., Lugassi, R., Ramon, U., Braun, O., Ben-Dor, E. (2007). Remote sensing as a tool for monitoring plasticulture in agricultural landscapes. International Journal of Remote Sensing, 28(1), 183-202. https://doi:10.1080/01431160600658156

Li, J., Pei, Y., Zhao, S., Xiao, R., Sang, X., Zhang, C. (2020). A review of remote sensing for environmental monitoring in China. Remote Sensing, 12, 1130.

Lu, L., Di, L., Ye, Y.A. (2014). Decision-tree classifier for extracting transparent plastic-mulched land cover from Landsat-5 TM images. IEEE J. Sel. Top. Appl. Earth Obs. Remote Sens, 7, 4548-4558.

Ma, A., Chen, D., Zhong, Y., Zheng, Z., Zhang, L. (2021). National-scale greenhouse mapping for high spatial resolution remote sensing imagery using a dense object 
dual-task deep learning framework: A case study of China. ISPRS Journal of Photogrammetry and Remote Sensing, 181, 279-294.

Novelli, A., Aguilar, M.A., Nemmaoui A., Aguilar, F.J., Tarantino, E. (2016). Performance evaluation of object based greenhouse detection from Sentinel-2 MSI and Landsat 8 OLI data: A case study from Almería (Spain). International Journal of Applied Earth Observation and Geoinformation, 52, 403-411.

Parra, S., Aguilar, F.J., Calatrava, J. (2008). Decision modelling for environmental protection: The contingent valuation method applied to greenhouse waste management. Biosystems Engineering, 99, 469-477.

Rezaeiniya, N., Ghadikolaei, A.S., Mehri-Tekmeh, J., Rezaeiniya, H. (2014). Fuzzy ANP approach for new application: greenhouse location selection; a case in Iran. Journal of Mathematics and Computer Science, 8, 1- 20.

Saltuk, B. (2019). Determination of greenhouse potential in Siirt Province and districts by using GIS and recommendations to producers. European Journal of Science and Technology, 15, 343-350.

Sang, L., Zhang, C., Yang, J., Zhu, D., Yun, W. (2011). Simulation of land use spatial pattern of towns and villages based on CA-Markov model. Mathematical and Computer Modelling, 54, 938-943.

Sonmez, N.K., Sari, M. (2006). Use of remote sensing and geographic information system technologies for developing greenhouse databases. Turkish Journal Of Agriculture and Forestry, 30, 413-420.

Sun, H., Wang, L., Lin, R., Zhang, Z., Zhang, B. (2021). Mapping plastic greenhouses with two-temporal Sentinel-2 images and 1D-CNN deep learning. Remote Sensing, 13, 2820. https://doi.org/10.3390/rs13142820

Tarantino, E., Figorito, B. (2012). Mapping rural areas with widespread plastic covered vineyards using true color aerial data. Remote Sensing, 4(7), 1913-1928. https://doi.org/10.3390/rs4071913

Themistocleous, K., Papoutsa, C., Michaelides, S., Hadjimitsis, D. (2020). Investigating detection of floating plastic litter from space using Sentinel-2 Imagery. Remote Sensing, 12, 2648.

Thompson, R.B., Padilla, F.M., Peña-Fleitas, M.T., Gallardo, M. (2020). Reducing nitrate leaching losses from vegetable production in Mediterranean greenhouses. Acta Horticulture, 1268, 105-117.

Wu, C.F., Deng, J.S., Wang, K., Ma, L.G., Tahmassebi, A.R.S. (2016). Object-based classification approach for greenhouse mapping using Landsat-8 imagery. International Journal of Agricultural and Biological Engineering, 9(1), 79-88.

Yang D., Chen, Z., Zhou, Y., Chen, X., Chen, X., Cao, X., (2017). Mapping plastic greenhouse with medium spatial resolution satellite data: Development of a new spectral index. ISPRS Journal of Photogrammetry and Remote Sensing, 128, 47-60. 